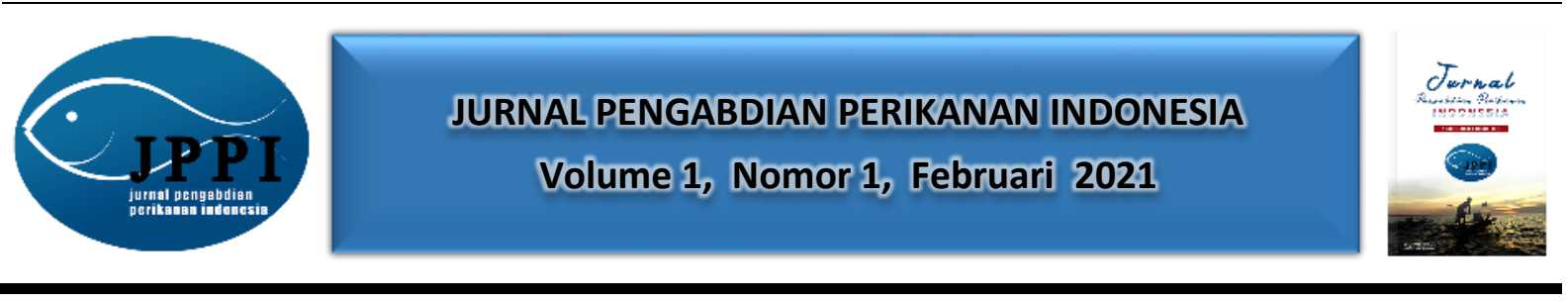

\title{
PENERAPAN TEKNOLOGI RECIRCULATING AQUACULTURE SYSTEM (RAS) UNTUK PERBAIKAN KUALITAS LINGKUNGAN PADA BUDIDAYA IKAN NILA DI DESA SOKONG KECAMATAN TANJUNG KABUPATEN LOMBOK UTARA
}

\author{
Bagus Dwi Hari Setyono ${ }^{1}$, Muhammad Junaidi ${ }^{1}$, Andre Rachmat Scabra ${ }^{1}$, Hendri \\ Kaswadi ${ }^{2}$
}

${ }^{1}$ Program Studi Budidaya Perairan Universitas Mataram, ${ }^{2}$ Dinas Perhubungan, Kelautan dan

Perikanan Kabupaten Lombok Utara

Jalan pendidikan Nomor 37 Kota Mataram

Alamat korespondensi : bagus.setyono@unram.ac.id

(Tanggal Submission: 3 Desember 2020, Tanggal Accepted : 2 Februari 2021)

Keyword: Abstrak:

RAS, nila, Desa Sokong terletak di Kecamatan Tanjung Kabupaten Lombok Utara yang memiliki kualitas air potensi pengembangan budidaya ikan nila. Aliran air Sungai Sokong selalu tersedia sepanjang tahun, namun debit airnya menurun pada musim kemarau. Kendala tersebut selalu dialami oleh masyarakat setiap tahunnya. Tujuan kegiatan pengabdian ini adalah masyarakat dapat menerapkan budidaya ikan nila menggunakan teknologi RAS (Recirculating Aquaculture System). RAS merupakan suatu teknologi untuk memanfaatkan media budidaya yang telah digunakan dalam sistem produksi untuk digunakan kembali layaknya air yang baru. Kelebihan penerapan teknologi ini adalah penggunaan air lebih hemat, kepadatan tebar tinggi, kemudahan dalam pemeliharaan, kemudahan dalam mempertahankan suhu dan kualitas air. Metode pengabdian adalah pembuatan demplot budidaya ikan nila menggunakan teknologi RAS. Filter yang digunakan berupa drum plastik kapasitas 200 liter menggunakan bahan penyaring batu apung. Hasil pengabdian menunjukkan budidaya ikan nila menjadi hemat air mencapai $70 \%$ serta kualitas air budidaya tetap bagus dengan nilai rata-rata $\mathrm{pH} 8,42$, suhu $31,6^{\circ} \mathrm{C}$, dan DO 5,1 mg. $\mathrm{I}^{-1}$. Selama 2,5 bulan pemeliharaan tingkat kelangsungan hidup mencapai $80 \%$. Teknologi RAS diharapkan menjadi solusi sehingga kegiatan budidaya dapat berjalan sepanjang tahun serta mampu meningkatkan ekonomi masyarakat.

Panduan Sitasi (APPA $7^{\text {th }}$ edition) :

Setyono, B.D.H., Junaidi, M., Scabra, A.R., \& Kaswadi, H. (2021). Penerapan Teknologi Recirculating Aquaculture System (Ras) Untuk Perbaikan Kualitas Lingkungan Pada Budidaya Ikan Nila Di Desa Sokong Kecamatan Tanjung Kabupaten Lombok Utara. Jurnal Pengabdian Perikanan Indonesia, 1 (1), 69-76. http://doi.org/ 10.29303/jppi.v1i1.128 


\section{PENDAHULUAN}

Potensi budidaya ikan air tawar di Kabupaten Lombok Utara (KLU) cukup besar. Areal budidaya air tawar (kolam) di KLU memiliki potensi sebesar 112 ha, namun pemanfaatannya baru 9,02\% atau sekitar 10,1 ha (KKP, 2018). Kendala yang dihadapi dalam pemanfaatan potensi tersebut adalah sumberdaya air yang terbatas dan tidak tersedia sepanjang tahun. Sebagai upaya untuk meningkatkan pemanfaatan budidaya air tawar perlu dilakukan suatu inovasi teknologi yang dapat diterapkan dan diterima oleh masyarakat.

Ikan nila (Oreochromis niloticus) merupakan salah satu komoditas perairan tawar yang banyak dibudidayakan di Provinsi NTB. Jumlah permintaan ikan nila selalu meningkat setiap tahunnya, terutama pada perayaan tahun baru, maulid Nabi Muhammad SAW, serta menjelang perayaan hari besar keagamaan lainnya. Berdasarkan data produksi ikan air tawar yang dirilis oleh KKP (2018), pada tahun 2013 produksi ikan nila NTB sebesar 16.631,68 ton, tahun 2014 sebesar 17.858,27 ton, tahun 2015 sebesar 17.016,59 ton, tahun 2016 sebesar 18.114,43 ton, dan tahun 2017 meningkat dua kali lipat lebih menjadi 44.017,31 ton. Jika dibandingkan dengan total produksi ikan nila NTB, kontribusi produksi ikan nila KLU masih minim. Berdasarkan data yang dirilis oleh BPS NTB (2018), kontribusi produksi ikan nila KLU terhadap total produksi NTB pada tahun 2015 adalah 15,9 ton atau kontribusi sekitar 0,09\% dan pada tahun 2016 menurun menjadi 11,06 ton atau kontribusi sebesar 0,06\%.

Desa Sokong memiliki potensi pengembangan budidaya air tawar yang cukup besar. Kondisi wilayah desa tersebut didominasi oleh lahan pertanian dan perkebunan yang relatif datar serta terdapat sungai dan saluran irigasi yang cukup memadai. Sungai Sokong menjadi batas wilayah antara Desa Tanjung dengan Desa Sokong dan Lokok Tengak. Masyarakat memanfaatkan sungai tersebut untuk kebutuhan sehari-hari seperti mencuci, mandi, dan pengairan lahan pertanian. Musim kemarau yang biasanya berlangsung pada Bulan April sampai Agustus, beberapa tahun terakhir menjadi tidak menentu sehingga berpengaruh pada hasil pertanian dan kegiatan perekonomian masyarakat.

Budidaya ikan air tawar di Desa Sokong dilakukan dengan sistem karamba (cage culture), kolam tanah, kolam semi permanen dan kolam terpal. Ikan air tawar yang banyak dibudidayakan yaitu ikan nila, ikan karper, dan ikan lele. Namun dalam perkembangannya, terdapat permasalahan dalam budidaya ikan air tawar, khususnya ikan nila yaitu debit air Sungai Sokong mengalami penurunan terutama pada musim kemarau dan produktivitas kolam yang rendah. Pada musim kemarau di beberapa lokasi budidaya ikan mengalami kekeringan, sehingga kegiatan budidaya menjadi terhenti.

Inovasi teknologi untuk mengatasi permasalahan tersebut perlu dilakukan, yaitu dengan mengaplikasikan sistem resirkulasi akuakultur atau lebih dikenal dengan Recirculating Aquaculture System (RAS). Teknologi RAS menawarkan sebuah alternatif teknologi budidaya melalui perbaikan kualitas air dan penggunaan kembali (re-use). Penggunaan RAS secara intensif terbukti dapat mengurangi secara signifikan konsumsi air dan konsentrasi nutrien melalui perbaikan dan pengembangan teknologi secara berkelanjutan (Thesiana dan Pamungkas, 2015). RAS dapat digunakan untuk mengontrol beberapa parameter kualitas air penting seperti oksigen terlarut, karbon dioksida, amonia, nitrit, nitrat, $\mathrm{pH}$, salinitas, dan padatan tersuspensi. Hal ini memungkinkan terciptanya kondisi pemeliharaan yang baik untuk pertumbuhan dan pemanfaatan pakan yang lebih optimal (Dalsgaard et al., 2013). 


\section{METODE KEGIATAN}

Kegiatan pengabdian dibagi menjadi tiga tahap, tahap pertama dimulai dengan alih teknologi, tahap kedua adalah penerapan teknologi, dan tahap ketiga adalah evaluasi kegiatan. Tahap pertama dimaksudkan untuk meningkatkan pengetahuan peserta tentang teknik budidaya ikan nila sesuai standar CBIB dan pengetahuan teknologi RAS baik secara prinsip maupun teknis. Metode kegiatan yang diterapkan adalah ceramah dan diskusi dengan media alih informasi yang interaktif (LCD Proyektor, Loud Speaker, Microfon) dan berlangsung dua arah. Untuk mengetahui tingkat pemahaman peserta tentang alih teknologi yang diberikan, tolok ukur yang digunakan adalah kuisioner yang diberikan sebelum (pre test) dan sesudah (post test) alih teknologi dilaksanakan.

Pada tahap kedua kegiatan penerapan teknologi yaitu pembuatan demonstration plot (demplot) dengan memberikan kesempatan kepada peserta untuk mempraktekkan langsung pembuatan filter dan sistem RAS. Peserta diberikan peralatan dan bahan yang dibutuhkan untuk selama 1 (satu) siklus produksi. Untuk mengetahui kemampuan peserta dalam praktek usaha budidaya ikan nila teknologi RAS yang mampu mempertahankan kualitas air. Tolok ukur yang digunakan adalah kemampuan peserta dalam meningkatkan pertumbuhan ikan selama 1 siklus produksi dan nilai parameter kualitas air yang diperoleh.

Tahap ketiga dilakukan evaluasi pada awal, pertengahan, dan akhir kegiatan. Evaluasi tahap awal dilakukan terhadap perencanaan awal yang telah disusun, evaluasi tahap pertengahan dilakukan terhadap penerapan rencana yang berkaitan sistem/metoda yang dijalankan, sedangkan evaluasi tahap akhir dilakukan terhadap keseluruhan kegiatan yang telah dilakukan. Selain evaluasi terhadap peningkatan pengetahuan dan keterampilan khayalak sasaran, evaluasi juga dilakukan terhadap teknologi RAS yang dijalankan, seperti pertumbuhan ikan, efisiensi pakan, tingkat kelangsungan hidup ikan, dan analisa keuntungan.

\section{HASIL DAN PEMBAHASAN}

\section{Peningkatan Pengetahuan Masyarakat}

Kegiatan pengabdian kepada masyarakat dengan judul Penerapan Teknologi Recirculating Aquaculture System (RAS) untuk Perbaikan Kualitas Lingkungan pada Budidaya Ikan Nila di Desa Sokong Kecamatan Tanjung Kabupaten Lombok Utara telah berlangsung dengan baik. Kegiatan diawali dengan ceramah dan diskusi tentang budidaya nila sesuai standar CBIB dan teknik budidaya menggunakan teknologi RAS. Kegiatan berikutnya adalah penerapan teknologi RAS dalam budidaya nila.

Cara Budidaya Ikan yang Baik (CBIB) merupakan sebuah konsep bagaimana memelihara ikan, agar ikan yang dipelihara memiliki kualitas yang baik dan meningkatkan daya saing produk, yaitu bebas kontaminasi bahan kimia maupun biologi dan aman untuk dikonsumsi. Disamping itu konsep CBIB juga membantu agar dalam proses pemeliharaan ikan menjadi lebih efektif, efisien, memperkecil resiko kegagalan, meningkatkan kepercayaan pelangggan, menjamin kesempatan eksport dan ramah lingkungan. Hal tersebut sesuai dengan Keputusan Menteri Kelautan dan Perikanan Nomor 02/MEN/2007 tentang Cara Budidaya Ikan yang Baik (CBIB). Dalam penerapan CBIB ada 4 Aspek yang harus diperhatikan, yaitu aspek teknis, aspek manajemen, aspek keamanan pangan dan aspek lingkungan.

RAS merupakan teknik budidaya yang relatif baru dalam industri perikanan. Sistem ini menggunakan teknik akuakultur dengan kepadatan tinggi di dalam ruang tertutup (indoor), serta 
kondisi lingkungan yang terkontrol sehingga mampu meningkatkan produksi ikan pada lahan dan air yang terbatas, meningkatkan produksi ikan sepanjang tahun, fleksibilitas lokasi produksi, pengontrolan penyakit dan tidak tergantung pada musim (Tetzlaff dan Heidinger, 1990). Sistem resirkulasi merupakan budidaya intensif yang merupakan alternatif menarik untuk menggantikan sistem ekstensif, dan cocok diterapkan di daerah yang memiliki lahan dan air terbatas (Suresh dan Lin, 1992).

RAS dibagi menjadi 2 macam, yaitu resikulasi penuh/tertutup dan resirkulasi sebagian/semi tertutup. Sistim resirkulasi tertutup, sistim resirkulasi yang mendaur ulang $100 \%$ air (CRS), sedangkan sistim resirkulasi semi tertutup, sistim resirkulasi yang mendaur ulang sebagian air buangan, sehingga masih membutuhkan penambahan air dari luar. Komponen dasar RAS terdiri dari :

1. Bak pemeliharaan ikan /tangki kultur (growing tank) yaitu tempat pemeliharaan ikan, dapat dibuat dari plastik, logam, kayu, kaca, karet atau bahan lain yang dapat menahan air, tidak bersifat korosif, dan tidak beracun bagi ikan.

2. Penyaring partikulat (sump particulate) yang bertujuan untuk menyaring materi padat terlarut agar tidak menyumbat biofilter atau mengkonsumsi suplai oksigen.

3. Biofilter merupakan komponen utama dari sistem resirkulasi. Biofilter merupakan tempat berlangsungnya proses biofiltrasi beberapa senyawa toksik seperti $\mathrm{NH}_{4}{ }^{+}$dan $\mathrm{NO}_{2}$. Pada dasarnya, biofilter adalah tempat bakteri nitrifikasi tumbuh dan berkembang.

4. Penyuplai oksigen (aerator) yang berfungsi untuk mempertahankan kadar oksigen terlarut dalam air agar tetap tinggi.

5. Pompa resirkulasi (water recirculation pump) yang berfungsi untuk mengarahkan aliran air. Peralatan yang digunakan pada sistem ini relatif mudah ditemukan dan sudah biasa digunakan, kecuali pompa air dan aerator.

\section{Penerapan Teknologi}

Penerapan teknologi RAS dimulai dengan pembuatan sistem filter. Bahan utama sistem filter adalah drum plastik bundar berkapasitas 200 liter, dengan diameter drum plastik $67 \mathrm{~cm}$ dan tinggi 90 $\mathrm{cm}$. Penggunaan drum plastik tersebut memiliki beberapa keunggulan, yaitu tebal dan kuat sehingga memiliki daya tahan yang lama, dapat menampung bahan penyaring dengan kapasitas besar serta tidak tembus cahaya matahari sehingga tidak mudah berlumut.

Langkah pembuatan filter dimulai dengan memotong bagian tutup drum plastik menggunakan gerindra. Saat pemotongan menggunakan gerindra, pinggiran tutup akan meleleh karena panas yang dikeluarkan akibat gesekan antara gerindra dengan drum plastik, sehingga harus menggunakan sarung tangan dan pelindung wajah. Bagian sisi drum ketinggian $73 \mathrm{~cm}$ dilubangi dengan diameter 1,5 inchi dan dipasang drat pipa yang berfungsi sebagai saluran keluar (outlet). Pada bagian bawah ketinggian $5 \mathrm{~cm}$ dibuat saluran backwash diameter $3 / 4$ inchi untuk memudahkan dalam membuang air kotor di dasar drum. 


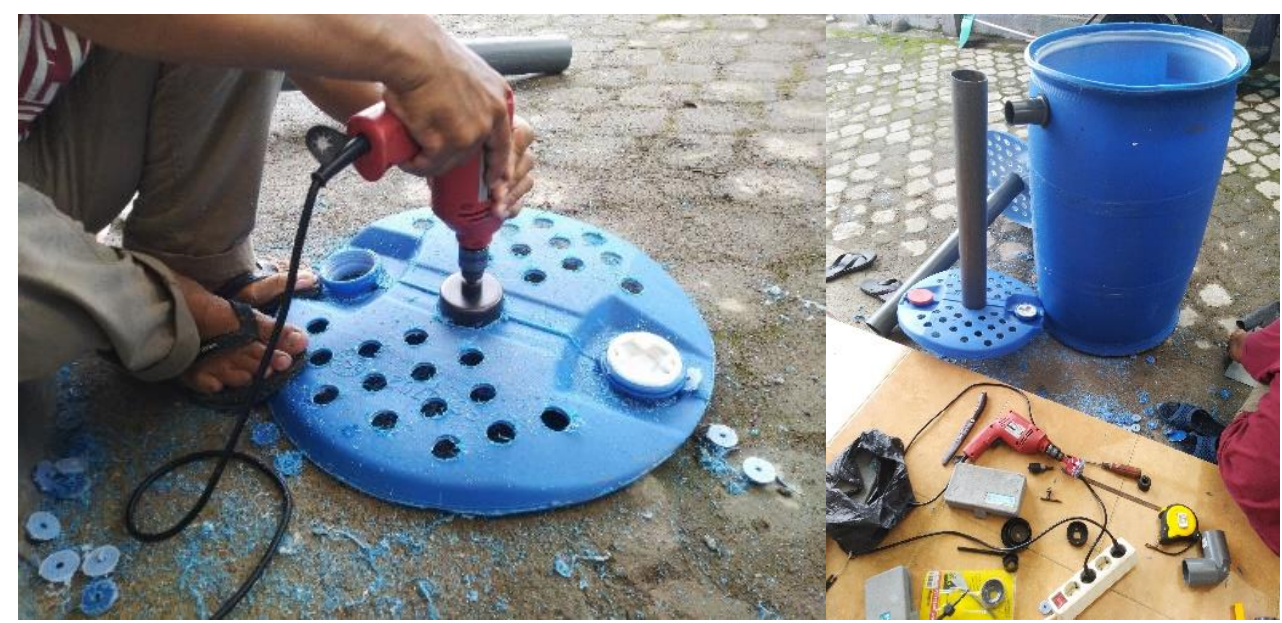

Gambar 1. Pembuatan Filter

Tutup drum yang sudah dipotong berbentuk bulat dilubangi menggunakan bor bermata bulat $1 / 2$ inchi pada bagian pinggirnya. Sedangkan pada bagian tengahnya dilubangi menggunakan bor dan dirapikan menggunakan gerindra agar pipa diameter 2 inchi bisa masuk. Selanjutnya pipa berdiameter 2 inchi dengan panjang $82 \mathrm{~cm}$ dimasukkan ke bagian tengah tutup drum yang sudah dilubangi. Pipa diameter 2 inchi berperan sebagai saluran air masuk (inlet) yang masuk ke dalam drum plastik.

Langkah berikutnya adalah memasukkan pipa 2 inchi dan tutup drum yang sudah dilubangi ke dalam drum. Jarak antara tutup drum yang sudah dilubangi dengan dasar drum sekitar $9 \mathrm{~cm}$ serta diberikan penyangga agar terdapat ruang kosong di bawah tutup drum. Setelah pipa 2 inchi berdiri tegak, selanjutnya dimasukkan batu apung ke bagian pinggir pipa (di atas tutup drum). Batu apung yang dimasukkan sebelumnya telah dikemas dalam kantong waring ukuran 40x50 cm untuk mudah diangkat kembali pada proses pencucian/pembersihan. Desain filter dapat dilihat pada Gambar 2.

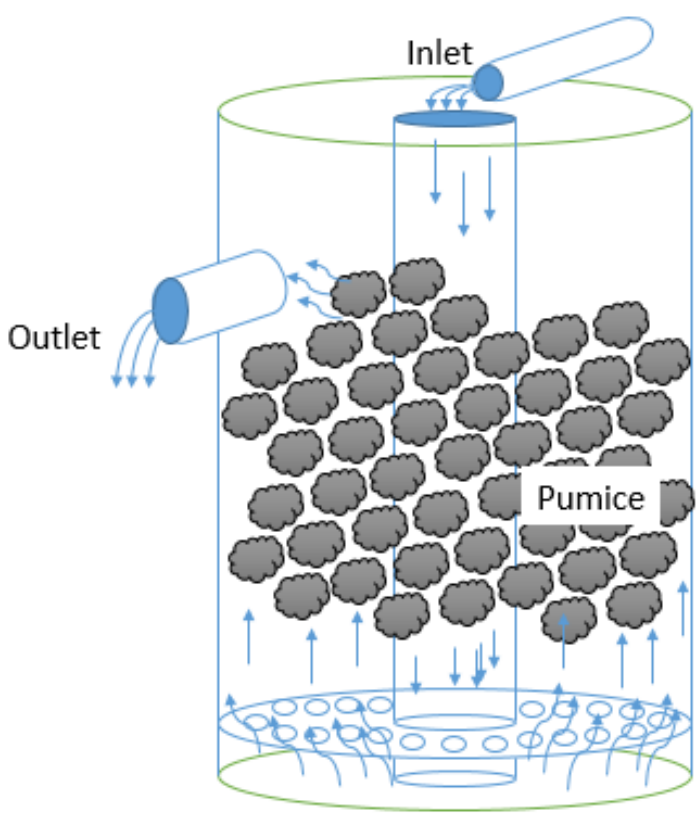

Sistem Filtrasi

Gambar 2. Desain Filter 
Sebelum digunakan bahan-bahan filter seperti drum, pipa, keran, dan drat pipa harus dicuci menggunakan sabun sampai bersih. Batu apung yang digunakan, terlebih dahulu harus direndam selama 24 jam bersih dari agar sisa-sisa kotoran atau pasir.

\section{Pemeliharaan Ikan Nila}

Ikan nila yang dipelihara menggunakan teknologi RAS menunjukkan pertumbuhan yang baik. Faktor yang mempengaruhi pertumbuhan ikan terdiri dari faktor internal dan eksternal. Faktor internal diantaranya adalah faktor keturunan, jenis kelamin, dan usia. Benih yang baik berasal dari induk berkualitas, benih ikan nila yang ditebar berasal dari Balai Benih Ikan (BBI) Batu Kumbung, Lingsar, Lombok Barat yang memiliki kualitas baik. Ukuran benih yang ditebar adalah 5-8 cm. Selama pemeliharaan benih diberi pakan berupa pellet komersil yang mengandung protein $29-32 \%$. Tingkat kelangsungan hidup ikan nila selama tiga bulan pemeliharaan sebesar $80 \%$. Penerapan teknologi RAS dapat dilihat pada Gambar 3.

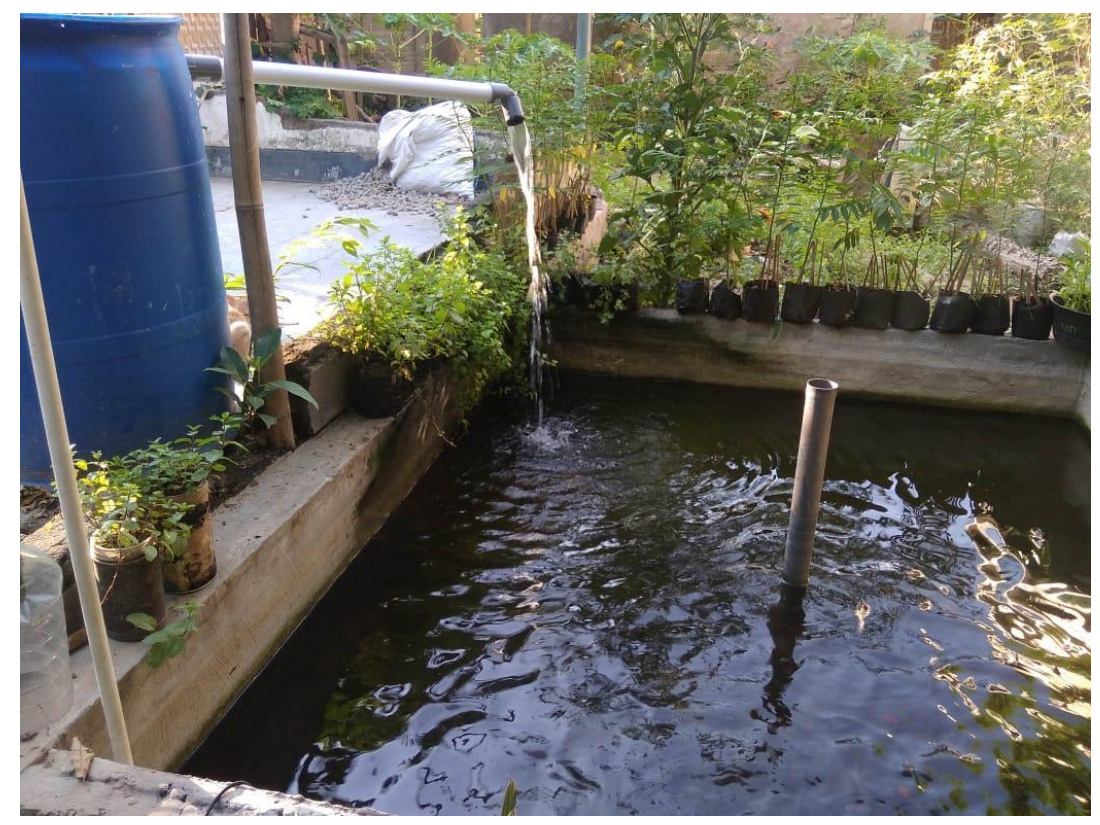

Gambar 3. Penerapan Teknologi RAS

Faktor eksternal yang mempengaruhi pertumbuhan ikan nila salah satunya adalah kualitas air. Kualitas air selama pemeliharaan tergolong cukup baik, hal ini dapat dilihat dari hasil pengukuran beberapa parameter kualitas air. Nilai pH pada media pemeliharaan adalah 8,42 , suhu sebesar $31,6^{\circ} \mathrm{C}$ dan kadar oksigen terlarut sebesar $5,1 \mathrm{mg} . \mathrm{l}^{-1}$. Sedangkan kualitas air pada filter drum plastik memiliki nilai pH sebesar 8,32 , suhu sebesar $31,6^{\circ} \mathrm{C}$ dan kadar oksigen terlarut sebesar $4,0 \mathrm{mg} . \mathrm{l}^{-1}$. Pengukuran kualitas air dapat dilihat pada Gambar 4. 


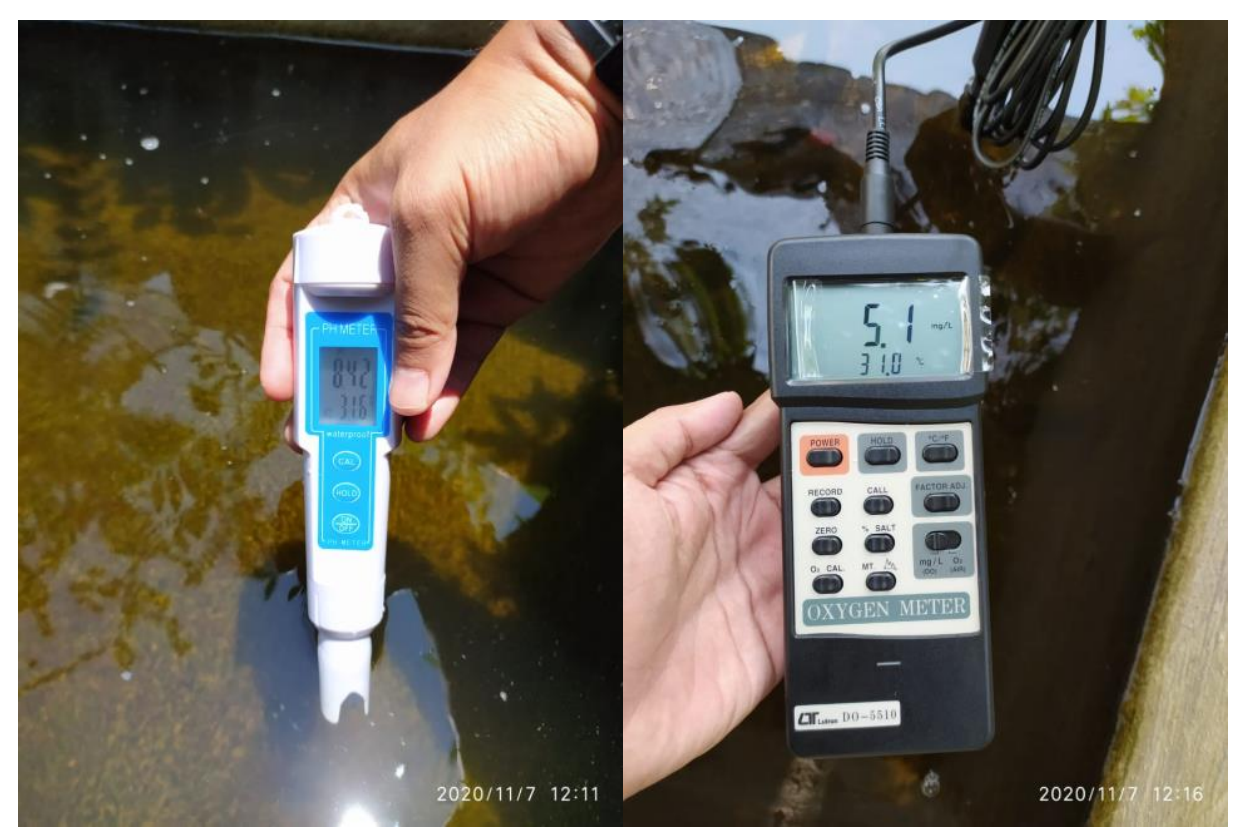

Gambar 4. Pengukuran Kualitas Air

Hasil pengukuran kualitas air masih dalam kisaran optimal bagi pertumbuhan ikan nila. Berdasarkan SNI 7550:2009 tentang Produksi Ikan Nila (Oreochromis niloticus Bleeker) Kelas Pembesaran di Kolam Air Tenang, kualitas air optimal untu suhu berkisar antara $25-32^{\circ} \mathrm{C}$, pH optimal berkisar antara 6,5-8,5 dan oksigen terlarut $\geq 3 \mathrm{mg}^{-1} \mathrm{I}^{-1}$. Secara visual penampakan air kolam selama pemeliharaan ikan terlihat sangat jernih.

\section{KESIMPULAN DAN SARAN}

\section{Kesimpulan}

Kegiatan pengabdian kepada masyarakat dengan judul Penerapan Teknologi Recirculating Aquaculture System (RAS) untuk Perbaikan Kualitas Lingkungan pada Budidaya Ikan Nila di Desa Sokong Kecamatan Tanjung Kabupaten Lombok Utara telah berlangsung dengan baik. Mitra sangat antusias dalam diskusi kegiatan yang dilaksanakan seperti penerapan CBIB dalam budidaya ikan nila dan teknologi RAS. Dalam penerapan teknologi RAS terbukti kualitas air tetap terjaga, baik secara kualitas maupun kuantitas. Budidaya ikan nila menggunakan filter drum plastik menjadikan penggunaan air hemat mencapai $70 \%$ serta kualitas air budidaya tetap bagus dengan nilai rata-rata $\mathrm{pH} 8,42$, suhu $31,6^{\circ} \mathrm{C}$, dan DO 5,1 mg. $\mathrm{l}^{-1}$. Selama 2,5 bulan pemeliharaan tingkat kelangsungan hidup mencapai $80 \%$.

\section{Saran}

Saran untuk kegiatan pengabdian adalah perlu dilakukan perawatan sistem filter secara periodik untuk menghilangkan lumut dan bahan lain yang mengganggu aliran air. Selama 2,5 bulan pemeliharaan, debit air pada sistem filter menurun. Saran untuk pembudidaya ikan air tawar, teknologi RAS layak untuk diaplikasikan untuk mendukung produksi. 


\section{UCAPAN TERIMA KASIH}

Tim pengabdian kepada masyarakat mengucapkan terima kasih kepada Universitas Mataram melalui Lembaga Penelitian dan Pengabdian Kepada Masyarakat (LPPM) Universitas Mataram yang telah mendanai kegiatan ini melalui dana DIPA BLU Universitas Mataram Tahun Anggaran 2020. Terima kasih juga kami ucapkan kepada Bapak Lalu Wiharjan yang telah membantu dalam pembuatan sistem filtrasi.

\section{DAFTAR PUSTAKA}

BPS. 2018. Kabupaten Lombok Utara Dalam Angka. CV. Maharani. Bandung

BSN (Badan Standar Nasional). 2009. Produksi Ikan Nila (Oreochromis niloticus Bleeker). Kelas Benih Sebar. BSN (Badan Standar Nasional). SNI 7550:2009. $12 \mathrm{hlm}$.

Dalsgaard, J., Lund, I., Thorarinsdottir, R., Drengstig, A., Arvonen, K., and Pedersen, P.B. 2013. Farming Different Species in RAS in Nordic Countries: Current Status and Future Perspectives. Journal of Aquacultural Engineering, 53, 2-13.

KKP. 2018. Potensi Usaha dan Peluang Investasi Kelautan dan Perikanan Provinsi Nusa Tenggara Barat. Direktorat Jenderal Penguatan Daya Saing Produk Kelautan dan Perikanan. Kementerian Kelautan dan Perikanan. Jakarta

Suresh, A. V. and Lin, C. K. 1992. Effect of Stocking Density on Water Quality and Production of Red Tilapia in Recirculated Water System, Aquacultural Engineering, page: 1-22.

Tetzlaff, B. L. and Heidinger, R. C. 1990. Basic Principles of Biofiltration and System Design, SIUC Fisheries Bulletin No. 9, SIUC Fisheries and Illinois Aquaculture Center.

Thesiana, L. Dan Pamungkas, A. Uji Performansi Teknologi Recirculating Aquaculture System (RAS) terhadap Kondisi Kualitas Air pada Pendederan Lobster Pasir Panulirus homarus. Jurnal Kelautan Nasional. Volume 10, Nomor 2, Halaman 65-73. 